\title{
Ticari kefirlerin bazı kalite parametrelerinin incelenmesi
}

\author{
Gülsüm ÖKSÜZTEPE ${ }^{1}$, Pelin DEMIR ${ }^{1}$, Pınar KARATEPE ${ }^{2}$, Selçuk ALAN , Müzeyyen AKGÖL ${ }^{1}$
}

${ }^{1}$ Firat Üniversitesi, Veteriner Fakültesi, Gıda Hijyeni ve Teknolojisi Bölümü, Elazığ/TÜRKIYYE

${ }^{2}$ Fırat Üniversitesi, Keban Meslek Yüksekokulu, Gıda İşleme Bölümü, Elazığ/TÜRKIYE

${ }^{3}$ Tarım ve Orman Bakanlığı, Veteriner Kontrol Enstitüsü, Elazığ/TÜRKIYE

Anahtar Kelimeler:

ticari kefir

halk sağlı̆̆1

kalite

Key Words:

commercial kefir

public health

quality

Gelis Tarihi : :17.03.2020

Kabul Tarihi : 10.05 .2020

Yayin Tarihi :25.06.2020

Makale Kodu :704987

Sorumlu Yazar:

G. ÖKSÜZTEPE

(gulsumoksuztepe@hotmail.com)

ORCİD:

G. ÖKSÜZTEPE: 0000-0003-3267-6841

P. DEMIR : :0000-0002-0824-1672

P. KARATEPE : 0000-0002-4698-9104

S. ALAN :0000-0002-4473-7835

M. AKGÖL : :0000-0002-8926-4509

\begin{abstract}
ÖZ
Bu çalışma Elazığ'da satılan 25'şer adet sade, meyveli ve light ticari kefir örneklerinin bazı kalite parametrelerini belirlemek için planlandi. Kefir örneklerinin mikrobiyolojik (toplam mezofilik aerob bakteri (TMA), Lactobacillus-Leuconostoc-Pediococcus (LLP), laktik streptokoklar, koliform, proteolitik ve lipolitik bakteri, maya ve küf, Escherichia coli, Staphylococcus-Micrococcus ve koagulaz pozitif Staphylococcus aureus) ve kimyasal ( $\mathrm{pH}$, asitlik, yağ, kuru madde, yağsız kuru madde ve kül) analizleri yapıldı. İncelenen tüm kefir çeşitlerinin hepsinin toplam mezofil aerob (TMA) ve koliform bakteri sayısı bakımından Türk Gıda Kodeksi Fermente Süt Ürünleri Tebliği’ne uygun olduğu görüldü. Maya sayısı bakımından sade $6(\% 24)$, meyveli $5(\% 20)$ ve light kefir örneklerinin ise $1(\% 4)$ tanesinin; küf sayısı bakımından sade $3(\% 12)$, meyveli $10(\% 40)$ ve light kefir örneklerinin ise $1(\% 4)$ tanesinin tebliğe uygunluk gösterdiği saptandı. Ayrıca asitlik ve yağ miktarı bakımından da incelenen tüm kefir örneklerinin tebliğe uygun olduğu görüldü.
\end{abstract}

\section{Investigation of some quality parameters of commercial kefir}

\begin{abstract}
This study was planned to determine some quality parameters of 25 plain, fruity and light commercial kefir samples retailed in Elazı $\breve{g}$. Kefir samples were analyzed for microbiological (total mesophilic aerob bacteria (TMAB), Lactobacillus-Leuconostoc-Pediococcus (LLP), lactic streptococci, coliform, proteolytic and lipolytic bacteria, yeast and mold, Escherichia coli, Staphylococcus-Micrococcus and coagulase positive Staphylococcus aureus) and chemical ( $\mathrm{pH}$, acidity, oil, dry matter, non-fat dry matter and ash). It was observed that all of the kefir varieties examined were in compliance with the Turkish Food Codex Fermented Dairy Notification in terms of total mesophile aerob bacteria (TMAB) and number of coliform bacteria. It was determined that in terms of yeast number $6(24 \%)$ of plain, $5(20 \%)$ of fruit and $1(4 \%)$ of light kefir samples were; in terms of number of molds $3(12 \%)$ of plain, 10 (40\%)of fruity and $1(4 \%)$ of light kefir samples were suitable for the notification. In addition, it was observed that all kefir samples examined in terms of acidity and oil amount were suitable for the notification.
\end{abstract}

\section{GİRİ̧}

Sağlıklı toplumların oluşması için sağlıklı bir yaşam biçimi vazgeçilmez unsurlardan biridir. Sağlıklı yaşamın temel prensibi dengeli ve yeterli beslenmektir. Dolayısıyla hayvansal proteinlere olan ihtiyaç gün geçtikçe artış göstermektedir. Bu bağlamda süt ve süt ürünleri çok değerli bir hayvansal protein kaynağıdır (1). Süt ürünleri içerisinde fermente süt ürünleri olarak bilinen grup insan beslenmesinde büyük önem arz etmektedir. Bu gruba dahil olan ürünler çoğunlukla laktik asit bakterileri tarafindan gerçekleştirilen fermentasyon olayı neticesinde oluşan kıvamı, aroması ve dayanma süresi farklı olan ürünlerdir. Bu ürünler dünyanın birçok yerinde değerli kabul edilen besin kaynaklarıdır (2).

Kefir uzun yıllardan beri tüketilen sağlık üzerine yararlı etkileri de olan ve tüketimi gün geçtikçe artış gösteren probiyotik bir süt ürünüdür. Kefir sütün içerisindeki temel besin bileșenle- rinin büyük bir kısmını bünyesinde barındırmasına ilaveten serinletici ve ferahlatıcı özelliğinden dolayı da kolaylıkla ve zevkle tüketilen fermente bir süt ürünüdür $(3,4)$. Kefirin anavatanı Kuzey Kafkaslardır. Yörede yaşayanların tesadüfi olarak inek ve keçi sütünden yaptıkları bir içecektir. Türkçe karşılığı olarak keyif verici, coșturucu, mest edici anlamlarına gelen 'keyf' kelimesinden köken alan kefirin; "kefer", "kephir", "kepi", "kipi”, "kiaphur" ve "kanapan" gibi isimleri de vardır (5). Kefir sadece Rusya'da değil birçok Avrupa ülkesinde ve Türkiye'de de tüketilmektedir. Buna ilaveten Amerika ve Japonya gibi ülkelerde de kefir tüketiminin son yıllarda yaygınlaştığı bildirilmektedir (6). Türk Gıda Kodeksi Fermente Süt Ürünleri Tebliği’ne (TGK-FSÜT) göre (7) kefirin tanımı șu șekilde ifade edilmektedir; "fermantasyonda spesifik olarak Leuconostoc, Lactobacillus, Acetobacter ve Lactococcus cinslerinin değişik suşları ve laktozu fermente eden (Kluyveromyces marxianus) ve etmeyen mayalan (Saccharomyces cerevisiae, Saccharomyces exigu- 
us ve Saccharomyces unisporus) kapsayan starter kültürler ya da kefir tanelerinin kullanıldığ1 fermente süt ürünü” dür (8).

Kefir; inek, koyun, keçi ve kısrak sütünün içerisine karnabahar görünümünde olan kefir granüllerinin katılması ile şekillenen, içerisinde etil alkol ve laktik asit fermantasyonlarının birlikte şekillendiği, çok az asidik yapıda olan ve aroması ile lezzeti kendine özgü olan fermente süt ürünü çeşididir. Kefir daha çok kefir granüllerinden veya granüllerden üretilen ana kültürden üretilmektedir (9). Kefir antibakteriyel (10), immunulojik (11), antitümoral $(12,13)$, anti-alerjik, anti-astimatik (14) ve hipokolesterolemik etkisinden dolayı sağlığa çok faydalıdır (15). Eski Sovyetler Birliği'nde kefir hastanelerde ve Sanatoryumlarda metabolik hastalıklar, arterosklerozis ve bazı alerjik hastalıkların tedavisinde kullanılmıştır (6). Aynı zamanda kefir triptofan, $\mathrm{Ca}$ ve $\mathrm{Mg}$ mineralleri bakımından da zengin olduğu için sinir sistemi ve sindirim sistemi hastalıklarında da kullanılmaktadir (13).

Kefirin kalitesini belirlemek için yapılan çalışmalar oldukça sınırlıdır. Kefirin mikrobiyal kalitesinin araştırıldığı bir araştır-

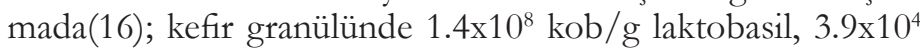
$\mathrm{kob} / \mathrm{g}$ laktokok ve $1.1 \times 10^{7} \mathrm{kob} / \mathrm{g}$ seviyesinde maya tespit edilmiştir. Withuhn ve ark. (17) kefir granüllerinden Lactobacillus spp., Leuconostoc spp., Lactococcus spp., Zygosaccharomyces, Candida ve Saccharomyces türlerini izole etmişlerdir. Kefir tanelerinin mikrobiyal florasını tespit etmek için ülkemizde yapılan deneysel bir araştırmada (18); kefir tanesinde $9.19 \log _{10}$ $\mathrm{kob} / \mathrm{ml}$ laktik asit bakterileri, $9.05 \log _{10} \mathrm{kob} / \mathrm{ml}$ laktobasiller, $8.87 \log _{10} \mathrm{kob} / \mathrm{ml}$ laktokok ve $6.55 \log _{10} \mathrm{kob} / \mathrm{ml}$ düzeyinde maya tespit edilmiştir. Yapılan bir başka çalışmada ise (3); 4 farklı firmaya ait toplam 120 adet kefir örneği incelenmiş ve incelenen kefir örneklerinde ortalama olarak toplam mezofilik aerob bakteri say1s1 $8.68 \log _{10} \mathrm{kob} / \mathrm{ml}$, laktobasil $8.33 \log _{10}$ $\mathrm{kob} / \mathrm{ml}$ ve maya sayıs ise $3.92 \log _{10} \mathrm{kob} / \mathrm{ml}$ olarak saptanmıştır. Aynı araștırmada kefir örneklerinin \% 15'inde enterokoklar, \% 11.6'sinda enterobakteriler, \% 32.5'inde koliform, \% 25.8 'inde fekal koliformlar ve \% 25'inde ise (30/120) E. coli bulunmuştur.

Türkiye'de ticari kefir tüketiminin artmasına paralel olarak üretilen kefirlerin halk sağlı̆̆ bakımından kalitesi ve güvenilirliği de önem kazanmaktadır. Bu çalıșma Elazı̆̆ piyasasında satılan sade, meyveli ve light ticari kefir örneklerinin bazı kalite parametrelerini tespit ederek mevcut standartlara uygun olup olmadığını belirlemek için planlandı.

\section{GEREÇ ve YÖNTEM}

Elazığ'da 1 Nisan-30 Haziran 2019 tarihleri arasında çeşitli şarküteri ve marketlerden farklı firmaların farklı seri numaralarından 25'şer adet sade, meyveli ve light olmak üzere toplam 75 adet endüstriyel kefir örneği satın alındı. Örnekler orijinal ambalajları içerisinde alınıp soğuk zincirde F. Ü. Vet. Fak. Gıda Hijyeni ve Teknolojisi Bölümü'ne getirilerek analizleri yapılıncaya kadar $+4^{\circ} \mathrm{C}$ de buzdolabinda muhafaza edildi.

\section{Mikrobiyolojik Analizler}

Mikrobiyolojik analiz olarak hem ana numuneden direkt 1 $\mathrm{mL}$ alındı hem de kefir örneklerinin her birisinden ayrı bir steril numune poşetine $10 \mathrm{~mL}$ tartıldı ve üzerine steril $1 / 4$ Ringer çözeltisinden $90 \mathrm{~mL}$ ilave edilerek parçalayıcıda (Bag Mixer Interscience 78860 St. France-Stomacher 400) homojen hale getirildi. Bu şekilde örneklerin $10^{-1}(1 / 10)$ lik dilüsyonları ve bu dilüsyondan da aynı seyrelticiyi kullanmak şartıyla örneklerin $10^{-9}$ ' a kadar olan desimal dilüsyonları hazırland1. Örneklerin her bir dilüsyonlarından 1'er ml kullanılarak çift seri halinde özel besi yerlerine dökme plak metoduyla ve $0.1 \mathrm{~mL}$ kullanılarak da yayma metoduyla ekimleri yapıldı. Ekimi yapılan petriler inkübasyona bırakıldı ve inkübasyon neticesinde 30-300 koloni içeren petriler sayıldı $(19,20)$.

Örneklerdeki TMAB sayımında PCA (Merck, Almanya) (21), LLP sayımında MRS (Biokar, Fransa) (19), Laktik Streptokokların sayımında M17 (Liofilchem) (22, 23), Koliformların say1minda VRB (Sharlav, İspanya) (22), Proteolitiklerin sayımında Calcium Caseinate (Conda Pronadisa, İspanya) (22), Lipolitiklerin sayımında Tributyrin (Liofilchem, Italya) (22), Mayaların sayımında Wort (Merck Almanya) (22), Küflerin sayımında Sabouraud Dextrose Agar (Merck, Almanya) (22), E. coli sayımında için TBX (Merck, Almanya) (24), Staphylococcus-Micrococcus ve koagulaz pozitif Staphylococcus aureus'un sayıminda BPA (Biokar, Fransa) besi yerleri tercih edildi. Ayrica koagulaz pozitif Staphylococcus aureus'un tespiti için ekimden sonra petri kutular1 $37 \pm 1{ }^{\circ} \mathrm{C}$ ' de 30 saat inkübasyona alındı. İnkübasyondan sonra petrilerde üreme gösteren parlak-siyah-pürüzsüz ve çevresinde zone olan koloniler ile atipik kolonilerden 5 tanesi seçilerek koagulaz test uygulandı $(25,26)$.

\section{Kimyasal Analizler}

Kimyasal olarak pH, asitlik, yağg, kuru madde, yağsız kuru madde ve kül analizleri yapıldı. $\mathrm{pH}$ analizleri $\mathrm{pH}$ metrede (Hanna) yapıldı (19). Asitliğin tespitinde (\% laktik asit) titrasyon (27), kuru madde ve kül miktarlarının tespitinde gravimetrik (28) ve yağ tayinin de ise Gerber Metodu (29) esas alınd1.

\section{İstatistik Analizler}

Çalışmanın istatistiksel değerlendirilmesi SPSS 22 (IBM SPSS, IBM Corporation, USA) paket program1 ile yapıldı. Normallik analizi sonuçlarına göre verilerin nonparametrik test varsayımlarını karşıladığı tespit edildi. Yapılan mikrobiyolojik ve kimyasal parametrelerin sade, meyveli ve light kefir örneklerinde grup içi karşılaştırılmasının değerlendirilmesinde Kruskal-Wallis H (K Independent Samples) ve Mann-Whitney $\mathrm{U}$ (2 Independent Samples) testlerinden faydalanıld1. İstatistiksel anlam $\mathrm{P} \leq 0.05$ düzeyinde verildi. Sonuçlar ortalama \pm standart sapma olarak değerlendirildi (30).

\section{BULGULAR}

Mikrobiyolojik parametreler Tablo 1'de ve Tablo 2'de kimyasal parametreler ise Tablo 3'de verilmektedir. Elde edilen istatistiksel bulgulara göre gruplar arasındaki farklilıkların Lactobacillus-Leuconostoc-Pediococcus, proteolitik, lipolitik, Staphylococcus - Micrococcus, maya, küf, pH, asitlik, yağ, kuru madde ve yağsız kuru madde bakımından önemli olduğu görüldü (Tablo 1 ve Tablo 3). 


\section{TARTIŞMA}

$\mathrm{Bu}$ çalışmada TMAB sayısı ortalama olarak ( $\log _{10} \mathrm{kob} /$ ml) sirasiyla sade, meyveli ve light kefir örneklerinde $7.43 \pm$ 0.36; $7.41 \pm 0.71 ; 7.56 \pm 0.17$ düzeyinde belirlendi (Tablo 1). İstatistiksel olarak gruplar arasındaki farklılıklar anlamlı değildi (P > 0.05) (Tablo 1). Polonya'da yapılan bir çalışmada (31) 61 adet kefir örneği incelenmiş ve TMAB sayıs1 $10^{7}-10^{9} \log _{10}$ kob/ $\mathrm{ml}$ düzeylerinde saptanmıştır. Dinç (3) yaptı̆̆ı çalışmasında ortalama olarak bu bakteri sayisinı sade kefirlerde $8.80 \log _{10}$ $\mathrm{kob} / \mathrm{ml}$, meyveli kefirlerde $8.51 \log _{10} \mathrm{kob} / \mathrm{ml}$ ve light kefirlerde ise $8.53 \log _{10} \mathrm{kob} / \mathrm{ml}$ olarak bulmuştur. Karabıyıklı ve Daștan (32) yapmış oldukları çalışmalarında endüstriyel kefir örneklerinde bu grup bakteriyi $7.24\left(\log _{10} \mathrm{kob} / \mathrm{ml}\right)$ olarak tespit etmişlerdir. Elde edilen sonuçların yukarıda belirtilen çalışma sonuçlarıyla benzerlik arz ettiği görülmektedir.

Lactobacillus-Leuconostoc-Pediococcus (LLP) bakterileri laktik asit bakterileri grubundan olup ürünlerin kendilerine has lezzeti, aroması ve dayanma süresi üzerine etki eden bakterilerdir. Kefir de fermente bir süt ürünü olduğu için laktik asit bakterilerinin aranması önem arz etmektedir. Özellikle bu grup bakteriler kefirin ana kaynağını oluşturan bakteri grubudur. Bu konuyla ilgili tebliğe (TGK-FSÜT) (7) göre kefirin toplam spesifik mikroorganizma düzeyinin en az $10^{7} \mathrm{kob} / \mathrm{ml}$ olmas gerektiği belirtilmektedir. Bu araştırmada sade, meyveli ve light kefir numunelerinde LLP sayısinın ortalama olarak sirasiyla $7.33 \pm 0.29 ; 6.86 \pm 0.76 ; 7.64 \pm 0.33 \log _{10} \mathrm{kob} / \mathrm{ml}$ düzeyinde olduğu belirlendi. Buna göre incelenen sade ve light kefir örneklerinin tebliğe uygun olduğu görüldü (Tablo 1). Sade ile meyveli gruplar arasinda tespit edilen farklilık anlamliydı (P $<0.000$ ) (Tablo 1). Tablo 2 incelendiği zaman sade ve light kefirlerin $25(\% 100)$ tanesinin meyveli kefirlerin ise $21(\% 84)$ tanesinin $>6 \log _{10} \mathrm{kob} / \mathrm{ml}$ düzeyinde LLP içerdiği saptandi. Meyveli örneklerin 4 tanesinde LLP sayısının $<6 \mathrm{log} / \mathrm{kob}$ olması muhtemelen üretim prosesinde ortayan çıkmış olan bir sorundan kaynaklanmıs olabilir. Sade kefir örneklerinde tespit edilen LLP sayılarının bazı araştırmacıların $(16,18,33,34)$ buldukları değerlerden $(8.60,10.15,8.00,9.05)$ düşük seviyelerde olduğu görüldü. Bu alanda yapılan çalışma sonuçlarılyla mevcut çalışma sonuçları arasındaki farklılıkların kefirin yapımında kullanılan starter kültür kombinasyonunun farklılı̆̆ından, kefirin üretim tekniğinden ve inkübasyon sıcaklığının farklılığından kaynaklanma ihtimali bulunmaktadır.

Laktik streptokoklar süt ürünleri üretiminde starter kültür olarak kullanılan bakteri grubudur. Özellikle bu grup bakteriler sütün içerisinde asit bir ortam oluşturarak sütün pıhtılaşmasına ve kefir içerisinde bulunan diğer bakterilerin üremesi için uygun bir durum oluşmasına katkıda bulanan bakteri grubudur. Çalışmada laktik streptokok sayısı ortalama olarak $\left(\log _{10} \mathrm{kob} /\right.$ ml) sirasiyla sade, meyveli ve light kefir örneklerinde $7.63 \pm$ $0.25 ; 7.79 \pm 0.46,7.67 \pm 0.27$ düzeyinde saptand1 (Tablo 1). Tüm gruplar arasindaki analiz sonuçlarının istatistiksel olarak anlamlı olmadığı belirlendi (P > 0.115) (Tablo 1). Tablo 2 incelendiği zaman bu grup bakterilerin incelenen tüm örneklerde $>6 \log _{10} \mathrm{kob} / \mathrm{ml}$ seviyesinde olduğu görülmektedir. Sade kefir örneklerinde tespit edilen değerin Güzel-Seydim'in (18)

bulduğu 8.87 değerinden düşük Ninane ve ark.'nın (16) bulduklar1 değerden ise nispeten yüksek değerde olduğu görüldü.
Bu grup bakterilerin sayısı ürünlerin genel mikroflorasındaki bakteri sayısının büyük bir oranını oluşturmaktadır. Kefir gibi fermente ürünlerde bu grup bakteri sayısının yüksek çıkması olağan bir durumdur.

Koliform grubu mikroorganizmalar hijyen indikatörü olarak aranan bakteri grubundan sayılmaktadırlar. Bunlar genellikle soframıza gelen son üründe tat, lezzet ve koku bozukluğuna neden olurlar (35). Koliform bakterileri sade kefir örneklerinin sadece $3(\% 12)$ tanesinde tespit edildi. Ortalama olarak 0.12 $\pm 0.33 \log _{10} \mathrm{kob} / \mathrm{ml}$ düzeyinde bulundu ve say1 1.0-1.99 $\log _{10}$ $\mathrm{kob} / \mathrm{ml}$ olarak saptand. Ancak meyveli ve light kefir örneklerinin hiç birinde tespit edilmedi (Tablo 1 ve Tablo 2). Ilgili tebliğde (TGK-FSÜT) (7) koliform say1s1 3 örnekte en fazla 9, 2 örnekte ise en fazla 95 olması gerektiği ifade edilmektedir (EMS). Buna göre incelenen tüm kefir örneklerinin tebliğe uygun olduğu saptandi. Polonya'da yapılan bir çalışmada (31) incelenen 61 adet sade kefir örneğinin sadece 3 tanesinde koliform bakterilerine rastlanıldığı ifade edilmektedir. Elde edilen bulguların bu çalışma sonuçlarıyla benzerlik arz ettiği görüldü.

İlgili tebliğde (TGK-FSÜT) (7) proteolitik ve lipolitik bakteriler için yasal bir limit bulunmamaktadır. Bu çalışmada ortalama olarak proteolitik bakteri sayısı sade, meyveli ve light kefirlerde sirayla $5.95 \pm 0.41 ; 7.08 \pm 0.89 ; 6.93 \pm 0.34$ ve lipolitik bakteri say1s1 ise sirayla $5.06 \pm 0.69 ; 6.46 \pm 0.96 ; 4.52 \pm 0.31$ $\left(\log _{10} \mathrm{kob} / \mathrm{ml}\right)$ düzeyinde tespit edildi (Tablo 1). Her iki bakteri grubu kendi arasında değerlendirildiğinde gruplar arasındaki farklılıklar anlamliyd1 $(\mathrm{P}<0.000)$ (Tablo 1). Tablo 2 incelendiği zaman sade kefirlerin 7 (\%28) tanesinde, meyveli kefirlerin $22(\% 88)$ tanesinde ve light kefirlerin ise $25(\% 100)$ tanesinde proteolitik bakteri sayisının; sade kefirlerin $2(\% 8)$ tanesinde ve meyveli kefirlerin ise $18(\% 72)$ tanesinde lipolitik bakteri sayıs1nın > $6.0 \log _{10} \mathrm{kob} / \mathrm{ml}$ olduğu görülmektedir.

Staphylococcus-Micrococcus say1s1 sade ve meyveli kefir örneklerinde ortalama olarak sirasiyla $0.28 \pm 0.51$ ve $0.24 \pm 0.52$ $\log _{10} \mathrm{kob} / \mathrm{ml}$ seviyesinde bulundu. Incelenen light kefir örneklerinin hiçbirinde ise üreme görülmedi (Tablo 1). İstatistiksel olarak gruplar arasındaki farklılıklar anlamlıdı $(\mathrm{P}<0.038)$ yanlış yazılmış (Tablo 1). Tablo 2 incelendiği zaman sade kefir örneklerinin sadece $6(\% 24)$ tanesinde meyveli kefir örneklerinin ise sadece 4 (\%16) tanesinde sayinin 1.0-1.99 $\log _{10} \mathrm{kob} / \mathrm{ml}$ arasında olduğu görülmektedir. Yapılan literatür araştırmaları neticesinde kefir çalışmalarında bu bakteri ile ilgili herhangi bir veriye rastlanılmamıştırBu grup bakterilerin bazı kefir örneklerinde üreme göstermemesi veya sayılarının çok az olması rekabetçi özelliklerinin zayıf olmasından kaynaklanmış olabilir. Ya da kefirin içerisinde bulunan laktik asit bakterilerinin üretmiş oldukları laktik asit, propiyonik asit, formik asit ve asetik asit gibi organik asitlerin ve hidrojen peroksit gibi metabolitlerin Staphylococcus grubu bakteriler üzerine de antagonistik etki yapmalarından kaynaklanmış olabilir.

Maya say1s1 ortalama olarak sirasiyla incelenen sade kefir örneklerinde $2.88 \pm 1.32$, meyveli kefir örneklerinde $2.47 \pm$ 1.82 ve light kefir örneklerinde ise $3.52 \pm 0.31 \log _{10} \mathrm{kob} / \mathrm{ml}$ olarak tespit edildi (Tablo 1). TGK-FSÜT'de (7) kefir örneklerinde bulunmas1 gereken maya say1s1 en az $10^{4} \mathrm{kob} / \mathrm{ml}$ olarak (hocam yazdığınız bilgilere katıliyorum. Ancak ticari firmalar farklı olduğu için almış olduğumuz örneklerde farklıydı. Etiket- 
teki bilgiler içeriği doğrulamıyorsa bu noktada tüketicilerin de aldatılması söz konusu olabiliyor.) belirtilmektedir. Bu değer dikkate alındığında incelenen sade kefir örneklerinin $6(\% 24)$, meyveli kefir örneklerinin $5(\% 20)$ ve light kefir örneklerinin ise $1(\% 4)$ tanesinin tebliğe uygunluk gösterdiği belirlendi (Tablo 2). Tüm gruplar arasındaki farlılıkların anlamlı olduğu görüldü $(\mathrm{P}<0.008)$ (Tablo 1). Dinç (3) yapmış olduğu çalışmasında sade kefirlerde 4.05, meyveli kefirlerde 3.23 ve light kefirlerde ise $2.60 \log _{10} \mathrm{kob} / \mathrm{ml}$ düzeyinde maya tespit etmiştir. Çalışma sonucunda elde edilen verilerin Dinç'in (3) sade ve meyveli kefirlerde bulduğu değerlerden düşük ancak light kefirlerde bulduğu değerlerden ise yüksek olduğu görüldü. Tespit edilen bu farklılık kefir üretim tekniğinden, kefir tanesinin orijininden, kullanılan starter kültürün çeşidinden ve kefirin mikrobiyel kompozisyonundan kaynaklanmış olabilir.

Küf sayis1 ortalama olarak sirasiyla incelenen sade kefir örneklerinde $3.05 \pm 1.37$, meyveli kefir örneklerinde $2.10 \pm 1.36$ ve light kefir örneklerinde ise $3.48 \pm 0.76 \log _{10} \mathrm{kob} / \mathrm{ml}$ olarak belirlendi (Tablo 1). TGK-FSÜT' ne (7) kefir örneklerinde bulunması gereken küf say1s1 en fazla $10^{2} \mathrm{kob} / \mathrm{ml}$ olarak ifade edilmektedir. Bu değer dikkate alındığında incelenen sade kefir örneklerinin 3 (\%12), meyveli kefir örneklerinin 10 (\%40) ve light kefir örneklerinin ise $1(\% 4)$ tanesinin tebliğe uygunluk gösterdiği saptandı (Tablo 2). İstatistiksel olarak gruplar arasindaki farklilıklar anlamlıdı $(\mathrm{P}<0.000)$ (Tablo 1). Karabiyıklı ve Daştan (32) yapmış oldukları çalışmalarında incelemiş oldukları kefir örneklerinin tamaminda küf sayısını $<1.0 \log _{10}$ $\mathrm{kob} / \mathrm{ml}$ olarak bulduklarını ifade etmektedirler. Bu araştırma bulgularıyla çalışmada elde edilen sonuçların uyum içerisinde olmadığ1 görülmektedir.

İncelenen tüm kefir örneklerinde E. coli ve Staphylococcus aureus bakterilerine rastlanilmadi.

pH değerinin incelenen tüm kefir örneklerinde 4.2-4.6 arasinda değişim gösterdiği belirlendi. Sade, meyveli ve light kefir örneklerinde ortalama olarak sirasiyla $\mathrm{pH}$ değeri $4.54 \pm 0.16$; $4.16 \pm 0.09 ; 4.08 \pm 0.26$ olarak tespit edildi (Tablo 3). Sonuçlara bakıldığında sadece sade kefir örneklerindeki değerlerin

Tablo 1. Kefir Örneklerinin Mikrobiyolojik Analiz Sonuçları $\left(\log _{10} \mathrm{kob} / \mathrm{ml}\right)$

Table 1. Microbiological Analysis Results of Kefir Samples ( $\left.\log _{10} \mathrm{kob} / \mathrm{ml}\right)$

\begin{tabular}{|c|c|c|c|c|c|}
\hline Mikroorganizma & $\begin{array}{c}\text { Örneğin Ad1 ve Sayısı } \\
\text { (n:25) }\end{array}$ & $\begin{array}{c}\text { Aritmetik Ortalama } \pm \text { Std } \\
\text { sapma }\end{array}$ & En az & En çok & Sig \\
\hline \multirow{3}{*}{ Toplam Mezofilik Aerob } & Sade & $7.43 \pm 0.36^{a}$ & 6.59 & 7.69 & \multirow{3}{*}{0.847} \\
\hline & Meyveli & $7.41 \pm 0.71^{\mathrm{a}}$ & 5.60 & 8.21 & \\
\hline & Light & $7.56 \pm 0.17^{\mathrm{a}}$ & 7.25 & 7.90 & \\
\hline \multirow{3}{*}{ Lactobacillus-Leuconostoc-Pedioccocus } & Sade & $7.33 \pm 0.29^{\mathrm{a}}$ & 6.79 & 7.65 & \multirow{3}{*}{$0.000^{* * *}$} \\
\hline & Meyveli & $6.86 \pm 0.76^{\mathrm{b}}$ & 5.15 & 7.51 & \\
\hline & Light & $7.64 \pm 0.33^{a}$ & 7.13 & 8.44 & \\
\hline \multirow{3}{*}{ Laktik Streptokoklar } & Sade & $7.63 \pm 0.25^{\mathrm{a}}$ & 7.38 & 8.30 & \multirow{3}{*}{0.115} \\
\hline & Meyveli & $7.79 \pm 0.46^{\mathrm{a}}$ & 6.62 & 8.23 & \\
\hline & Light & $7.67 \pm 0.27^{a}$ & 7.00 & 8.11 & \\
\hline \multirow{3}{*}{ Koliform } & Sade & $0.12 \pm 0.33^{\mathrm{a}}$ & 0.00 & 1.00 & \multirow{3}{*}{0.046} \\
\hline & Meyveli & $0.00 \pm 0.00^{a}$ & 0.00 & 0.00 & \\
\hline & Light & $0.00 \pm 0.00^{a}$ & 0.00 & 0.00 & \\
\hline \multirow{3}{*}{ Proteolitik Bakteri } & Sade & $5.95 \pm 0.41^{\mathrm{b}}$ & 4.99 & 6.86 & \multirow{3}{*}{$0.000 * * *$} \\
\hline & Meyveli & $7.08 \pm 0.89^{a}$ & 5.11 & 7.71 & \\
\hline & Light & $6.93 \pm 0.34^{a}$ & 6.30 & 7.56 & \\
\hline \multirow{3}{*}{ Lipolitik Bakteri } & Sade & $5.06 \pm 0.69^{\mathrm{b}}$ & 4.00 & 6.40 & \multirow{3}{*}{$0.000^{* * *}$} \\
\hline & Meyveli & $6.46 \pm 0.96^{a}$ & 4.78 & 7.37 & \\
\hline & Light & $4.52 \pm 0.31^{\mathrm{c}}$ & 4.08 & 5.61 & \\
\hline \multirow{3}{*}{ Staphylococcus-Micrococcus } & Sade & $0.28 \pm 0.51^{\mathrm{a}}$ & 0.00 & 1.30 & \multirow{3}{*}{$0.038^{*}$} \\
\hline & Meyveli & $0.24 \pm 0.52^{a}$ & 0.00 & 2.00 & \\
\hline & Light & $0.00 \pm 0.00^{\mathrm{b}}$ & 0.00 & 0.00 & \\
\hline \multirow{3}{*}{ Maya } & Sade & $2.88 \pm 1.32^{\mathrm{b}}$ & 0.00 & 4.56 & \multirow{3}{*}{$0.008^{* *}$} \\
\hline & Meyveli & $2.47 \pm 1.82^{\mathrm{b}}$ & 0.00 & 5.84 & \\
\hline & Light & $3.52 \pm 0.31^{a}$ & 0.00 & 4.03 & \\
\hline \multirow{3}{*}{ Küf } & Sade & $3.05 \pm 1.37^{\mathrm{b}}$ & 0.00 & 3.95 & \multirow{3}{*}{$0.000^{* * *}$} \\
\hline & Meyveli & $2.10 \pm 1.36^{c}$ & 0.00 & 3.73 & \\
\hline & Light & $3.48 \pm 0.76^{a}$ & 0.00 & 3.97 & \\
\hline
\end{tabular}

a, b, c : Aynı sütündaki farklı harfleri taşıyan gruplar arasındaki farklılıklar önemlidir;

*** $: \mathrm{P}<0.001, * *: \mathrm{P}<0.01, * \quad: \mathrm{P}<0.05-0.01$ 
standartlara uygun olduğu ancak meyveli ve light kefir örneklerindeki değerlerin ise uygunluk göstermediği görülmektedir. İstatistiksel farklıklar önemliydi $(\mathrm{P}<0.000)$ (Tablo 3). Sade kefir örneklerinde tespit edilen değerin bazı araştırmacıların (42, 46) buldukları $(4.50,4.55)$ değerlerle benzerlik gösterdiği bulundu. Dinç (3) yapmış olduğu çalışmasında $\mathrm{pH}$ değerini sade kefir örneklerinde 4.26, meyveli kefir örneklerinde 4.13 ve light kefir örneklerinde ise 4.17 olarak bulmuştur. Bu çalışma sonuçlarının mevcut çalışma sonuçlarından düşük seviyelerde olduğu görülmektedir. Ticari kefir örneklerinin yapımında kullanılan sütlerin kalitesi, kuru madde miktarı, kefir örneklerini oluşturan starter kültürün kombinasyonu, sütün mayalanma sicaklığ1, ve fermantasyon süresi $\mathrm{pH}$ değerinde görülen farklılıklarda etkili olabilmektedir.

Asitlik değeri (1.a) ortalama olarak sade, meyveli ve light kefirlerde sirasiyla $0.74 \pm 0.04,0.73 \pm 0.09,0.81 \pm 0.05$ olarak saptand1 (Tablo 3). 'TGK-FSÜT' ne göre (7) kefirdeki asitlik miktarının alt limitinin \% 0.6 olması gerektiği vurgulanmaktadır. Tespit edilen sonuçların tebliğe uygunluk gösterdiği bulundu. Sade ve light kefir örneklerinde saptanan değerlerin Dinç'in (3) bulduğu değerlerle (sade: 0.78; light: 0.81) uyum içerisinde olduğu ancak meyveli kefirlerde saptanan değerin (0.73) ise nispeten az olduğu gözlemlendi (Tablo 3). Gruplar arasındaki farklilıklar önemliydi $(\mathrm{P}<0.000)$ (Tablo 3). Meyveli kefir örneklerindeki asitlik değerinin yüksek olması muhtemelen kefire ilave edilen meyvelerden, katılan starter kültürün tipi ve miktarından, inkübasyon süresinden ve sıcaklığından kaynaklanmış olabilir.

Ortalama yağ miktarı sade, meyveli ve light kefirlerde sırasiyla $2.53 \pm 0.41 ; 2.13 \pm 0.48 ; 100 \pm 0.00$ olarak tespit edildi (Tablo 3). TGK-FSÜT' de (7) kefirdeki yağ miktarı en fazla \% 10 olarak belirtilmiştir. Elde edilen sonuçların tebliğe uygunluk gösterdiği belirlendi. Sade kefir örneklerinde bulunan değerlerin bazı araştırmacıların (34) sade kefir örneklerinde buldukları

Tablo 3. Kefir Örneklerinin Kimyasal Analiz Sonuçları.

Table 3. Chemical Analysis Results of Kefir Samples.

\begin{tabular}{|c|c|c|c|c|c|}
\hline Analiz & $\begin{array}{l}\text { Örneğin Adı ve Sayısı } \\
(n: 25)\end{array}$ & $\begin{array}{l}\text { Aritmetik Ortalama } \pm \\
\text { Standart sapma }\end{array}$ & En az & En çok & Sig \\
\hline \multirow{3}{*}{$\mathrm{pH}$} & Sade & $4.54 \pm 0.16^{\mathrm{a}}$ & 4.21 & 4.72 & \multirow{3}{*}{$0.000 * * *$} \\
\hline & Meyveli & $4.16 \pm 0.09^{b}$ & 4.05 & 4.38 & \\
\hline & Light & $4.08 \pm 0.26^{b}$ & 3.76 & 4.44 & \\
\hline \multirow{3}{*}{ Asitlik (\%l.a) } & Sade & $0.74 \pm 0.04^{\mathrm{b}}$ & 0.72 & 0.81 & \multirow{3}{*}{$0.000 * * *$} \\
\hline & Meyveli & $0.73 \pm 0.09^{\mathrm{b}}$ & 0.49 & 0.90 & \\
\hline & Light & $0.81 \pm 0.05^{\mathrm{a}}$ & 0.72 & 0.90 & \\
\hline \multirow{3}{*}{ Yă̆ $(\%)$} & Sade & $2.53 \pm 0.41^{\mathrm{a}}$ & 1.80 & 3.00 & \multirow{3}{*}{$0.000 * * *$} \\
\hline & Meyveli & $2.13 \pm 0.48^{b}$ & 1.20 & 2.80 & \\
\hline & Light & $1.00 \pm 0.00^{c}$ & 1.0 & 1.0 & \\
\hline \multirow{3}{*}{ Kuru Madde (\%) } & Sade & $10.00 \pm 0.84^{\mathrm{b}}$ & 6.46 & 10.79 & \multirow{3}{*}{$0.000 * * *$} \\
\hline & Meyveli & $13.74 \pm 1.43^{\mathrm{a}}$ & 11.23 & 15.91 & \\
\hline & Light & $7.90 \pm 0.14^{c}$ & 7.62 & 8.23 & \\
\hline \multirow{3}{*}{ Yağsız Kuru Madde (\%) } & Sade & $7.48 \pm 1.03^{\mathrm{b}}$ & 3.76 & 8.77 & \multirow{3}{*}{$0.000 * * *$} \\
\hline & Meyveli & $11.61 \pm 1.68^{\mathrm{a}}$ & 8.43 & 14.07 & \\
\hline & Light & $6.90 \pm 0.14^{c}$ & 6.62 & 7.23 & \\
\hline \multirow{3}{*}{ Kül (\%) } & Sade & $1.01 \pm 1.09^{\mathrm{a}}$ & 0.11 & 4.24 & \multirow{3}{*}{0.276} \\
\hline & Meyveli & $0.86 \pm 0.80^{\mathrm{a}}$ & 0.28 & 3.11 & \\
\hline & Light & $0.51 \pm 0.09^{\mathrm{a}}$ & 0.33 & 0.65 & \\
\hline
\end{tabular}


Tablo 2. Kefir Örneklerinde Mikroorganizmaların Sayısal Dağılımı $\left(\log _{10} \mathrm{kob} / \mathrm{ml}\right)$

Table 2. Numerical Distribution of Microorganisms in Kefir Samples $\left(\log _{10} \mathrm{kob} / \mathrm{ml}\right)$

\begin{tabular}{|c|c|c|c|c|c|c|c|c|c|c|c|c|c|c|c|}
\hline \multirow{2}{*}{ Mikroorganizma } & \multirow{2}{*}{$\begin{array}{l}\text { Numune } \\
\text { Say1s1 } \\
(\mathrm{n}: 25)\end{array}$} & \multicolumn{2}{|c|}{$0-0.99$} & \multicolumn{2}{|c|}{ 1.0-1.99 } & \multicolumn{2}{|c|}{$2.0-2.99$} & \multicolumn{2}{|c|}{$3.0-3.99$} & \multicolumn{2}{|c|}{$4.0-4.99$} & \multicolumn{2}{|c|}{$5.0-5.99$} & \multicolumn{2}{|c|}{$>6$} \\
\hline & & $\mathrm{n}$ & $\%$ & $\mathbf{n}$ & $\%$ & $\mathrm{n}$ & $\%$ & $\mathbf{n}$ & $\%$ & $\mathrm{n}$ & $\%$ & $\mathbf{n}$ & $\%$ & $\mathbf{n}$ & $\%$ \\
\hline \multirow{3}{*}{ Toplam Mezofilik Aerob } & Sade & - & - & - & - & - & - & - & - & - & - & - & - & 25 & 100 \\
\hline & Meyveli & - & - & - & - & - & - & - & - & - & - & 1 & 4 & 24 & 96 \\
\hline & Light & - & - & - & - & - & - & - & - & - & - & - & - & 25 & 100 \\
\hline \multirow{3}{*}{$\begin{array}{l}\text { Lactobacillus-Leuconos- } \\
\text { toc-Pediococcus }\end{array}$} & Sade & - & - & - & - & - & - & - & - & - & - & - & - & 25 & 100 \\
\hline & Meyveli & - & - & - & - & - & - & - & - & - & - & 4 & 16 & 21 & 84 \\
\hline & Light & - & - & - & - & - & - & - & - & - & - & - & - & 25 & 100 \\
\hline \multirow{3}{*}{ Laktik Streptokoklar } & Sade & - & - & - & - & - & - & - & - & - & - & - & - & 25 & 100 \\
\hline & Meyveli & - & - & - & - & - & - & - & - & - & - & - & - & 25 & 100 \\
\hline & Light & - & - & - & - & - & - & - & - & - & - & - & - & 25 & 100 \\
\hline \multirow{3}{*}{ Koliform } & Sade & 22 & 88 & 3 & 12 & - & - & - & - & - & - & - & - & - & - \\
\hline & Meyveli & 25 & 100 & - & - & - & - & - & - & - & - & - & - & - & - \\
\hline & Light & 25 & 100 & - & - & - & - & - & - & - & - & - & - & - & - \\
\hline \multirow{3}{*}{ Proteolitik } & Sade & - & - & - & - & - & - & - & - & 1 & 4 & 17 & 68 & 7 & 28 \\
\hline & Meyveli & - & - & - & - & - & - & - & - & - & - & 3 & 12 & 22 & 88 \\
\hline & Light & - & - & - & - & - & - & - & - & - & - & - & - & 25 & 100 \\
\hline \multirow{3}{*}{ Lipolitik } & Sade & - & - & - & - & - & - & - & - & 13 & 52 & 10 & 40 & 2 & 8 \\
\hline & Meyveli & - & - & - & - & - & - & - & - & 4 & 16 & 3 & 12 & 18 & 72 \\
\hline & Light & - & - & - & - & - & - & - & - & 24 & 96 & 1 & 4 & - & - \\
\hline \multirow{3}{*}{$\begin{array}{l}\text { Staphylococcus-Micro- } \\
\text { coccus }\end{array}$} & Sade & 19 & 76 & 6 & 24 & - & - & - & - & - & - & - & - & - & - \\
\hline & Meyveli & 20 & 80 & 4 & 16 & 1 & 4 & - & - & - & - & - & - & - & - \\
\hline & Light & - & - & - & - & - & - & - & - & - & - & - & - & - & - \\
\hline \multirow{3}{*}{ Maya } & Sade & 3 & 12 & - & - & 6 & 24 & 10 & 40 & 6 & 24 & - & - & - & - \\
\hline & Meyveli & 6 & 24 & - & - & 10 & 40 & 4 & 16 & 2 & 8 & 3 & 12 & - & - \\
\hline & Light & 1 & 4 & - & - & & & 23 & 92 & 1 & 4 & & & - & - \\
\hline \multirow{3}{*}{ Küf } & Sade & 3 & 12 & - & - & 4 & 16 & 18 & 72 & - & - & - & - & - & - \\
\hline & Meyveli & 6 & 24 & 4 & 16 & 7 & 28 & 8 & 32 & - & - & - & - & - & - \\
\hline & Light & 1 & 4 & - & - & - & - & 24 & 96 & - & - & - & - & - & - \\
\hline
\end{tabular}

a, b, c : Aynı sütündaki farklı harfleri taşıyan gruplar arasındaki farklılıklar önemlidir;

*** $: \mathrm{P}<0.001, * *: \mathrm{P}<0.01, *: \mathrm{P}<0.05-0.01$

değerlerden (3.08 ve 3.51) oldukça düşük seviyelerde olduğu belirlendi. Ancak Dinç'in (3) sade (2.83), meyveli (2.93) ve light (1.04) kefir örneklerinde buldukları değerlerle nispeten uyum içerisinde olduğu görülmektedir. İstatistiki olarak gruplar arasındaki farkliliklar önemliydi $(\mathrm{P}<0.000$ ) (Tablo 3). Görülen bu farklılıkların muhtemelen kefir üretiminde kullanılan sütün standardizasyonundan kaynaklanabileceği tahmin edilmektedir.

Sade, meyveli ve light kefir örneklerinde kuru madde miktarlar1 ortalama olarak sirasiyla $10.00 \pm 0.84 ; 13.74 \pm 1.43 ; 7.90$ \pm 0.14 iken yağsız kuru madde miktarı $7.48 \pm 1.03 ; 11.61 \pm$
1.68; $6.90 \pm 0.14$ olarak belirlendi (Tablo 3). Bulunan bu değerlerin Dinç'in (3) sade (11.20), meyveli (17.63) ve light (10.50) ile Irigoyen ve ark.'nın (42) buldukları 11.70 değerinden nispeten düşük seviyelerde olduğu görülmektedir. Gruplar arasındaki farkliliklar önemliydi $(\mathrm{P}<0.000)$ (Tablo 3). Meyveli kefir örneklerinde kuru madde miktarının daha yüksek olarak tespit edilmesinin nedeni meyve püresi kullanımından kaynaklanmıș olabilir. Kefirin üretim tekniği, kullanılan sütün kalitesi, üretim esnasinda uygulanan standardizasyon ve diğer işlem parametrelerindeki farklılıklar kefirin kuru madde miktarını etkileyebilmektedir. 
Kül miktarı genellikle g1da maddelerinde inorganik madde miktarı olarak tanımlanmaktadır. Ürünlerde çok fazla miktarda olması arzu edilmez. Çünkü bu değer ürünlerin hijyenik şartlarda üretilmediklerinin ve insan sağllğına zarar verebilecek bazı inorganik maddeleri içerebildiğinin bir göstergesi olarak kabul görmektedir. Sade, meyveli ve light kefir örneklerinde kül miktarları ortalama olarak sirasiyla $1.01 \pm 1.09$; $0.86 \pm 0.08$; $0.51 \pm 0.09$ olarak tespit edildi (Tablo 3). Kefir çeşitleri arasındaki farklılıklar istatistiksel olarak anlamlı değildi $(\mathrm{P}>0.276)$ (Tablo 3). Tebliğ'de kefir örneklerinde bulunması gereken kül miktarı ile ilgili herhangi bir değer olmadığı için tartışma yapılamamaktadır. Bilindiği üzere meyveli yoğurtların yapımında kullanılan meyve püresi gibi katkı maddeleri ürünün kuru madde miktarının yüksek çıkmasını etkilemektedir. Buna rağmen kül miktarının daha düşük seviyelerde olması muhtemelen kullanılan bu tür ilave maddelerin yeterince pastörize edilmiş olduğunu ve üretim prosesinde gerekli hijyenik önlemlerin alınmış olabileceğini akla getirmektedir.

\section{SONUÇ}

Analiz edilen tüm kefir örneklerinin büyük çoğunluğunun ilgili tebliğde belirtilen hem mikrobiyolojik ve hem de kimyasal bazı kalite parametrelerine uygun oldukları görüldü.

Ancak incelenen numune sayisinin az olmasi genelleme yapmamı noktasinda sinırlar getirmektedir. Bununla birlikte üretilen endüstriyel kefir ürünlerinin sağlıklı, güvenilir ve kaliteli bir şekilde halka ulaştırılması için üretimden tüketime kadar tüm proseslerde HACCP (Hazard Analysis and Critical Control Points), GMP (Good Manifucture Practice) ve GHP (Good Hygiene Practice) kurallarının uygulanması büyük önem arz etmektedir.

\section{KAYNAKLAR}

1. Öksüztepe G, Patır B, Dikici A, İlhak Oİ. Elazığ'da tüketime sunulan vakum paketli taze kaşar peynirlerinin mikrobiyolojik ve kimyasal kalitesi. Firat Üniv Sağ Bil Vet Derg 2009;23(2):8994.

2. Biçer Y, Uçar G. Fermente Sütler. Süt ve Süt Ürünleri, Atasever, M. (ed), 1. Bask1, Türkiye Klinikleri, Ankara, Türkiye, 2019; s. 146-152.

3. Dinç A. Kefirin bazı mikrobiyolojik ve kimyasal özelliklerinin belirlenmesi. Yüksek Lisans Tezi, Ankara Üniversitesi Sağlık Bilimleri Enstitüsü Besin Hijyeni ve Teknolojisi Anabilim Dalı, Ankara, Türkiye, 2008.

4. Yetişemeyen A. Süt Teknolojisi. Ankara Üniversitesi Ziraat Fakültesi Yayınları, 1995, 1420: 220.

5. Koroleva NS. Technology of kefir and kumys. International Dairy Federation Bulletin 1988227: 96-100.

6. Angulo L, Lopez E, Lema C. Microflora present in kefir grains of the Galician region (North-West of Spain). J. Dairy Res. 1993;60:263-267.

7. Anonymus. Türk Gıda Kodeksi. Fermente Süt Ürünleri Tebliği (2009/2). Tarım ve Köyișleri Bakanlığı, Ankara, Türkiye, 2009.
8. Tomar O, Çağlar A, Akarca G. Kefir ve sağlık açısından önemi. Afyon Kocatepe Üniversitesi Fen ve Mühendislik Bilimleri Dergisi 2017;17:834-853.

9. Karatepe P, Yalçın H. Kefirli sağlık. Iğdır Üniversitesi Fen Bilimleri Enstitüsü Dergisi 2014;4(2):23-30.

10. Zacconi C, Parisi MG, Sarra PG, Dallavalle P, Bottazzi V. Competitive exclusion of Salmonella Kedougou in kefir fed chicks. Microbiologie, Aliments, Nutrition 1995;12:387-390.

11. Furukawa N, Matsuoka A, Yamanaka Y. Effects of orally administered yogurt and kefir on tumor growth in mice. Journal of Japanese Society of Nutrition and Food Science 1990;43:450-453.

12. Furukawa N, Matsuoka A, Takahashi T, Yamanaka Y. Effects of fermented milk on the delayed type hypersensitivity response and survival day in mice bearing meth-A. Animal Science and Technology 1991;62:579-585.

13. Köroğlu Ö, Bakır E, Uludağ G, Köroğlu S, Dayısoylu KS. Kefir ve sağlık. Kahramanmaraş Sütçü İmam Üniversitesi Doğa Bilimleri Dergisi 2015;18(1):26-30.

14. Ergin F, Öz G, Özmen Ü, Erdal Ş, Çavana E, Küçükçetin A. Sütün homojenizasyonunun kefirin fizikokimyasal ve mikrobiyolojik özellikleri üzerine etkisi. Akademik Gida 2017;5(4):368-376.

15. Tamai Y, Yoshimitsu N, Watanabe Y, Kuwabara Y, Nagai S. Effect of milk fermented by culturing with various lactic acid bacteria and a yeast on serum cholesterol level in rats. Journal of Fermentation Bioengineering 1996;81:181-182.

16. Ninane V, Berben G, Romnee JM, Oger R. Variability of the microbial abundance of a kefir grain starter cultivated in partially controlled conditions. Biotechnol. Agron. Soc. Environ. 2005;9(3):191-194.

17. Withuhn RC, Schoeman T, Britz TJ. Characterisation of the microbial population at different stages of kefir production and kefir grain mass cultivation. Int. Dairy J. 2005;15:383389.

18. Güzel-Seydim ZB, Wyffels JT, Seydim AC, Greene AK. Turkish kefir and kefir grains: microbial enumeration and electron microscobic observation. Int. J. Dairy Tech. 2005;58(1):25-29.

19. APHA. American Public Health Association: Standarts methods for the examination of dairy products. 15th edn., American Public Health Association, New York, the USA, 1995.

20. Harrigan WF. Laboratory Methods in Food Microbiology, 3rd Edition. Academic Pres., London, 1998.

21. Maturin LJ, Peeler JT. Aerobic plate count. In, Bacteriological Analytical Manual, Chapter 3, 2001. http:// www.cfsan. fda.gov/ebam/bam-3htm/26.01.2018.

22. Halkman AK. Gıda Mikrobiyolojisi Uygulamaları. Başak Matbaacilik, Ankara, Türkiye, 2005. 
23. Terzaghi BE, Sandine WE. Improve medium for lactic streptococci and their bacteriophages. Appl Microbiol. 1975;29:807-813.

24. ISO 16649-2/2001. Microbiology of food and animal feding stuffs-Horizontal method for the detection and enumeration of $\beta$-glucuronidase-positive Escherichia coli. Part 2, Colony-count technique a $44^{\circ} \mathrm{C}$ using 5 -brome-4chloro-3-indoly-beta-D-glucuronide. Geneve, Switzerland.

25. ISO 6888-1:1999/AMD 1/2003. Coagulase (+) Staphylococcus aureus identification. http://www.iso.org/iso/iso_catalogue/07.04.2018.

26. Lancette GA, Bennett RW. Staphylococcus aureus and staphylococcal enterotoxins. In, Downes, F.P., Ito K (Eds), 4th Edition, Microbiological Examination of Foods, American Public Health Association, Washington DC, USA, 2001; 387-404p.

27. Anonymus. Çiğ İnek Sütü Standardı. Türk Standardlanı Enstitüsü, Ankara, Türkiye, 2015a.

28. AOAC. Association of Official Analytical Chemists. Official Methods of Analysis. 14th Edition, Association of Analytical Chemists, Washington DC, the USA, 1984.

29. Anonymus. Çiğ Süt Yağ Muhtevası Tayini. TS ISO 2446. Türk Standardları Enstitüsü, Ankara, Türkiye, 2015b.

30. Özdamar K. SPSS ile Biyoistatistik. Kaan Kitapevi, 3. Bask1, Eskişehir, Türkiye, 1999.

31. Molska I, Nowosielska R, Frelik I. Changes in microbiological quality of kefir and yoghurt on the Warsaw market in the years 1995-2000, Rocz Panstw Zakl Hig 2003; 54(2):145152

32. Karabıyıklı Ş, Daştan S. Geleneksel ve fonksiyonel bir gida olan kefirin mikrobiyolojik profili. Gaziosmanpaşa Üniv Zir Fak Derg 2016;33(1):75-83.

33. Mainville I, Montpetit D, Durand N, Farnworth ER. Deactivating the bacteria and yeast in kefir using heat treatment, irradiation and high pressure. Int. Dairy J. 2001;11:45-49.

34. Irigoyen A, Arana I, Castiella M, Torre P, Ibanez FC. Microbiological, physicochemical and sensory characteristics of kefir during storage. Food Chem. 2005;90:613-620.

35. İnal T. Süt ve Süt Ürünleri Hijyen ve Teknolojisi. Final Ofset, İstanbul, Türkiye, 1990; s. 559- 566. 